\title{
Wpływ momentu napędowego i hamującego na bezpieczeństwo ruchu pojazdu trakcyjnego po torze zakrzywionym o małym promieniu krzywizny
}

\begin{abstract}
$W$ artykule przedstawiono i przedyskutowano konsekwencje wynikajace z chwilowego doprowadzenia do osi zestawów kót momentu hamujacego lub napędowego $w$ sytuacji, gdy lokomotywa czteroosiowa porusza się z dopuszczalna prędkościa po torze zakrzywionym o małym promieniu krzywizny. Wykorzystano możliwości obliczeniowe specjalistycznego programu Adams Rail, przeznaczonego do badania dynamiki pojazdów szynowych. Analizowano proces wykolejenia będacy wynikiem wspinania się obrzeża koła na główkę szyny. We wszystkich podjętych dziataniach ocenę poziomu zagrożenia bezpieczeństwa ruchu sprowadzono do analizy wskaźników wykolejenia na kołach zestawu prowadzqcego, z uwzględnieniem zarówno kąta nabiegania, kata niedostatku przechytki jak również pionowych nacisków kót na szyny wynikajacych z położenia zestawu kót w torze zakrzywionym.
\end{abstract}

\section{Wprowadzenie}

Przedstawiona w artykule dyskusja dotyczy lokomotywy poruszającej się z dopuszczalną prędkością po torze zakrzywionym o małym promieniu krzywizny i ogranicza się do analizy procesu wykolejenia powstającego w wyniku wspinania się obrzeża koła na główkę szyny - rys.1.1. Bezpieczeństwo ruchu trakcyjnego pojazdu szynowego w bardzo dużym stopniu zależne jest od położenia $\mathrm{w}$ torze zestawów kół, na które w czasie jazdy przekazywane są momenty napędowe lub hamujące, pionowe obciążenia od nadwozia oraz obciążenia wzdłużne i poprzeczne od elementów zawieszenia. Pojedynczy, konwencjonalny zestaw kół, w którym dwa stalowe koła o nominalnych promieniach toczenia $r_{k}$ osadzone są sztywno na wspólnej osi, przedstawiono na rys.1.2. Przyjęto, że na wirujący z prędkością kątową $\omega$ zestaw kół, poruszający się po torze zakrzywionym opisanym przez takie podstawowe parametry, jak: promień krzywizny środkowej linii toru $R$, rozstaw szyn $2 s$ oraz przechyłkę $h_{T}$, działa dodatkowo przyłożony $\mathrm{w}$ osi moment napędowy $M_{n}$ lub hamujący $M_{h}$.

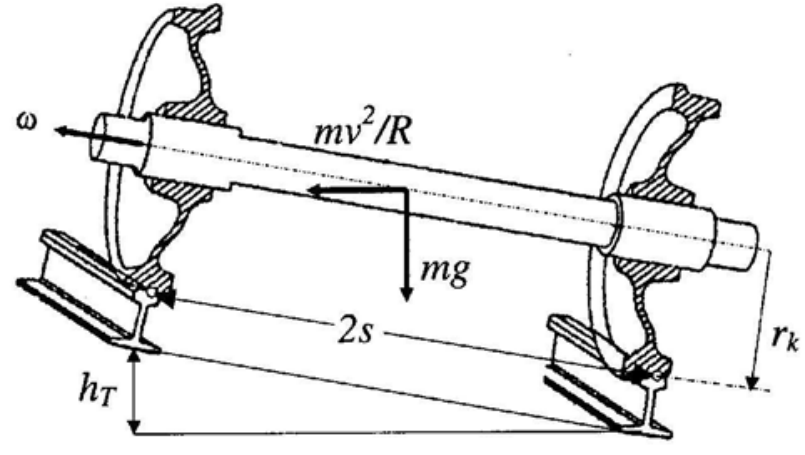

Rys.1.2. Konwencjonalny zestaw kół w położeniu na pełnym łuku toru zakrzywionego

Uwzględniono także niedostatek przechyłki. Zerowy kąt niedostatku przechyłki toru wystapi wtedy, gdy odśrodkowa siła bezwładności, działająca na poruszający się wzdłuż toru $\mathrm{z}$ ustaloną prędkością $v$ zestaw kół o masie $m$, zrównoważona zostanie przez

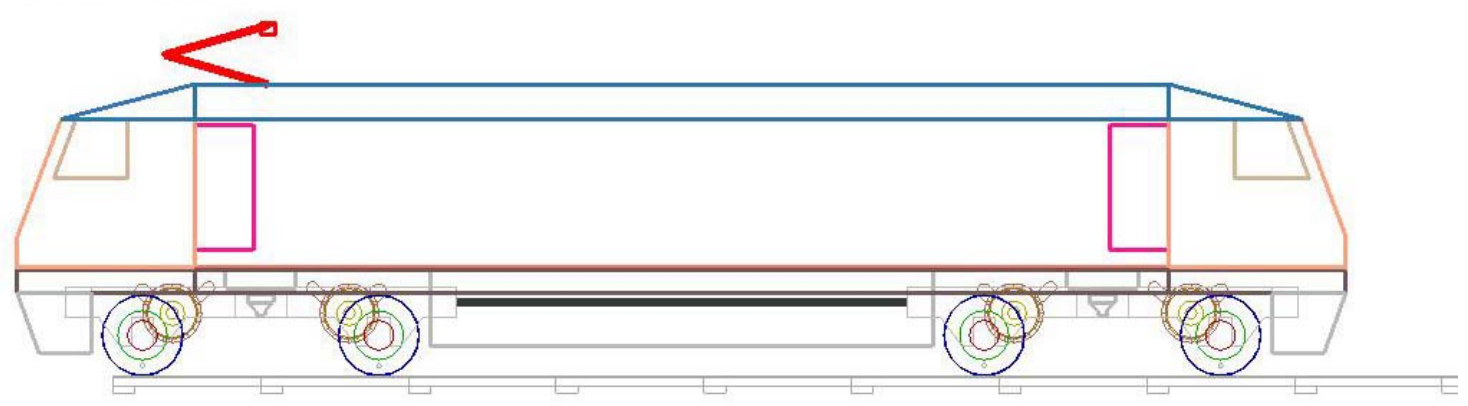

Rys.1.1. Szkic badanego w programie Adams Rail modelu lokomotywy 
poprzeczną składową siły ciężkości tego zestawu. Równanie równowagi jest wówczas następujące: $m g$ $\left(v^{2} / g R-h_{T} / 2 s\right)=0$. Człon $\Phi=v^{2} / g R-h_{T} / 2 s$ opisuje niedostatek przechyłki wyrażony $\mathrm{w}$ radianach, zaś symbol $g$ oznacza przyśpieszenie ziemskie.

Oprócz poprzecznego przemieszczenia względem linii środkowej toru zestaw kół ustawia się również względem szyny zewnętrznej pod kątem nabiegania $\psi$, którego wielkość w dużym stopniu zależy od parametrów zawieszenia pojazdu. $\mathrm{Na}$ rys.1.3 przedstawiono przyjętą $\mathrm{w}$ obliczeniach interpretację dodatniego oraz ujemnego kąta nabiegania koła na szynę na torze zakrzywionym. Przebieg procesu wykolejenia podzielić można na kilka faz - rys.1.4. Najpierw obrzeże koła zagrożonego wykolejeniem dociśnięte zostaje do wewnętrznej powierzchni główki szyny zewnętrznej. Współpraca obrzeża koła z szyną $\mathrm{w}$ takiej postaci oznacza kołnierzowe prowadzenie zestawu kół $\mathrm{w}$ torze zakrzywionym i jest początkową fazą wykolejenia.

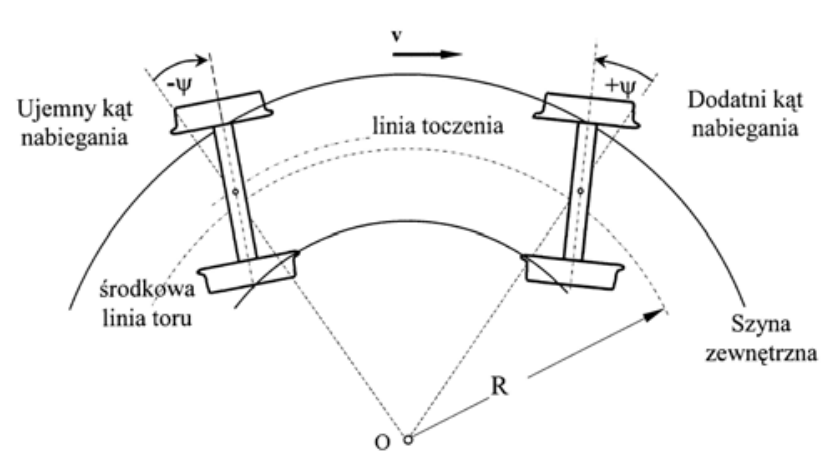

Rys.1.3. Interpretacja znaków kąta nabiegania koła na zewnętrzną szynę na torze zakrzywionym - [4]
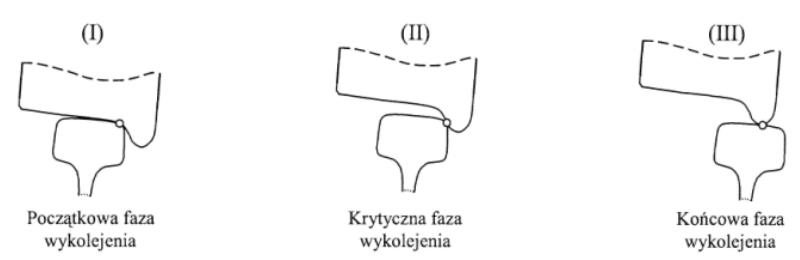

Rys.1.4. Fazy procesu wykolejenia zestawu kół - [4]

Sukcesywne zwiększanie się kąta styku obrzeża koła z szyną połączone jest ze wspinaniem się obrzeża na główkę szyny. W krytycznej fazie wykolejenia kąt styku osiaga maksymalną, możliwą do uzyskania wartość, następnie zmniejsza się i obserwowana jest końcowa faza połączona $\mathrm{z}$ gwałtownym przemieszczeniem poprzecznym koła będącego już na górnej powierzchni główki szyny oraz wypadnięciem całego zestawu kół z toru kolejowego.

Stosowane do oceny poziomu zagrożenia wykolejeniem kryteria podają graniczną wartość stosunku sił $Y / Q$ (czyli siły prowadzącej koło, którego obrzeże wspina się na główkę szyny, do pionowej reakcji szyny na to koło - rys.1.5) w odniesieniu do pojedynczego koła lub dwóch kół w zestawie i mają charakter quasi-statyczny $-[9,10,11]$. Wektory sił $\boldsymbol{Y}$ i $\boldsymbol{Q}$ są składowymi siły wypadkowej $\boldsymbol{R}=\boldsymbol{N}+\boldsymbol{T}$ na kierunku poprzecznym i pionowym, przy czym $N$ jest wektorem siły normalnej, natomiast $\boldsymbol{T}$ wektorem siły stycznej w obszarze kontaktu obrzeża koła z szyną.

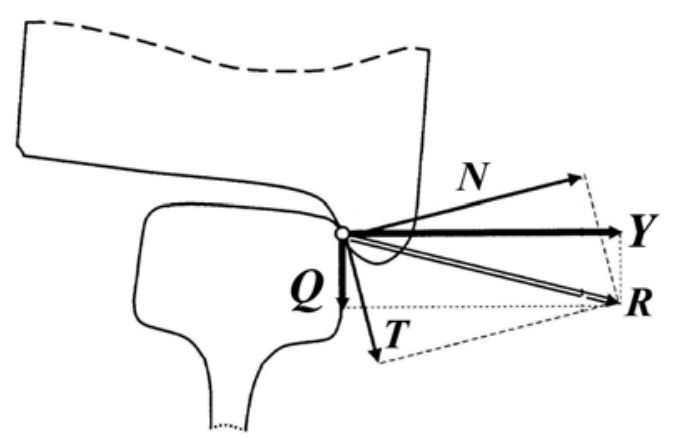

Rys.1.5. Płaski układ równowagi sił w obszarze styku obrzeża koła wspinającego się na szynę

Zalecane przez przepisy kolejowe kryteria dotyczące wykolejenia nie uwzględniają kąta nabiegania koła na szynę $\psi$. Najbardziej znane jest kryterium Nadala, ustalające maksymalną wartość wskaźnika wykolejenia $Y / Q$ wynikającą z równowagi sił w płaszczyźnie styku obrzeża koła z szyną - [2]. Przyjmując, że $\gamma$ jest największym, możliwym do zrealizowania kątem styku, zaś $\mu$ jest współczynnikiem tarcia pomiędzy kołem i szyną, Nadal wyprowadził następujące równanie równowagi sił w obszarze styku obrzeża koła z szyną przy zerowej wartości kąta nabiegania oraz bez uwzględniania wzdłużnych sił stycznych: $Y / Q=(\operatorname{tg} \gamma-$ $\mu) /(1+\mu \operatorname{tg} \gamma)$. Kryterium oceniające stan zagrożenia na podstawie analizy zsumowanych wartości wskaźników wykolejenia na dwóch kołach tego samego zestawu zaproponowane zostało przez Weinstocka i ma postać: $Y / Q=(\operatorname{tg} \gamma-\mu) /(1+\mu \operatorname{tg} \gamma)+\mu$. W formule tej na kole, którego obrzeże styka się z szyną, wskaźnik $Y / Q$ obliczany jest $\mathrm{z}$ równania Nadala, natomiast w przypadku drugiego koła wskaźnik utożsamiany jest $\mathrm{z}$ wartością współczynnika tarcia $\mu$ pomiędzy tym kołem i szyną wewnętrzną.

Jak już wspomniano, obowiązujące kryteria służące do oceny poziomu zagrożenia wykolejeniem praktycznie nie uwzględniają składowych wzdłużnych sił stycznych. Badania doświadczalne potwierdziły jednak znaczący udział tych właśnie sił w procesie wspinania się obrzeża koła na główkę szyny - [10]. Dlatego prowadzona w artykule dyskusja dotyczy wpływu sił stycznych, zarówno w odniesieniu do początkowej, jak i krytycznej fazy wykolejenia - [4,7]. Siły te, jak również moment $\mathrm{w}$ obszarze styku koła $\mathrm{z}$ szyną przedstawiono poglądowo na rys.1.6. 
$T_{x}, T_{y}, M_{z}$ oznaczają odpowiednio wzdłużne i poprzeczne siły styczne oraz moment wywołany istnieniem poślizgu poprzecznego i spinu. Założono, że koło nabiega na szynę pod kątem $\psi$ oraz styka się $\mathrm{z}$ nią pod kątem $\gamma$, w punkcie leżącym na obrzeżu koła. Przyjmując, że na torze zakrzywionym maksymalna wartość wypadkowej siły stycznej $T \mathrm{w}$ obszarze styku obrzeża koła z szyną podlega prawu Coulomba, można napisać:

$$
|T|=\mu \cdot N=\sqrt{T_{x}^{2}+T_{y}^{2}} .
$$

W równaniu (1.1) $\mu$ oznacza współczynnik tarcia pomiędzy kołem i szyną, $N$ siłę normalna, natomiast $T_{x}, \quad T_{y} \quad$ to odpowiednio składowa wzdłużna $\mathrm{i}$ poprzeczna wypadkowej siły $T$.

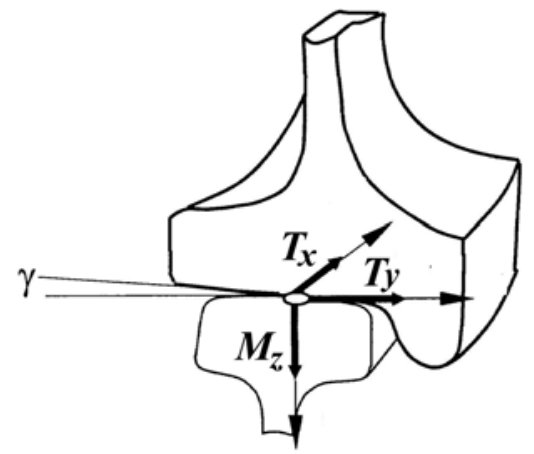

Rys.1.6. Siły styczne i moment wywołany poślizgami poprzecznymi i spinem w obszarze styku koła z szyną

Uwzględniając wyprzedzenie nabiegania koła na szynę, zdefiniowano kąt $\alpha$, o jaki układ współrzędnych związany z kołem obróci się wokół osi wirowania zestawu kół. Następnie wprowadzono siły bezwymiarowe:

$$
t_{x}=T_{x} / T, t_{y}=T_{y} / T,
$$

z myślą o ustaleniu ich udziałów w wypadkowej sile stycznej, która uległa nasyceniu (saturacji). $Z$ warunku saturacji wynika, że:

$$
\sqrt{t_{x}^{2}+t_{y}^{2}}=1
$$

Biorąc pod uwage związek pomiędzy siłami $Y$ i $Q$ w punkcie styku koła z szyną oraz równania (1.1), (1.2) i (1.3) otrzymano następujące równanie - [4]: nowego pożądane jest, aby kryterialne wartości wskaźników wykolejenia były jak największe. Wyniki obliczeń dla przypadku $\psi=0, \alpha=0$ oraz dwóch różnych maksymalnych wartości kąta styku obrzeża koła $\mathrm{z}$ szyna $\left(\gamma=60^{\circ}\right.$ i $\left.\gamma=70^{\circ}\right)$, przedstawiono na rys.1.7 i rys.1.8. Prowadzą one do wniosku, że w ogólnym bilansie sił stycznych działających w obszarze styku obrzeża koła z szyną decydujący wpływ na kryterialną wartość wskaźnika wykolejenia $|Y / Q|_{k r}$ ma wzdłużna siła styczna. Przy całkowitym braku tej siły (tzn. gdy $t_{x}=0$ i $\left.t_{y}=1\right)$, wskaźnik $|Y / Q|_{k r}$ osiaga najmniejszą wartość, która odpowiada wartości obliczonej $\mathrm{z}$ równania Nadala. Jednocześnie maksymalne wartości $|Y / Q|_{k r}$ uzyskiwane są wtedy, gdy $t_{x}=1$ oraz $t_{y}=0$, czyli przy całkowitym braku poprzecznej siły stycznej.

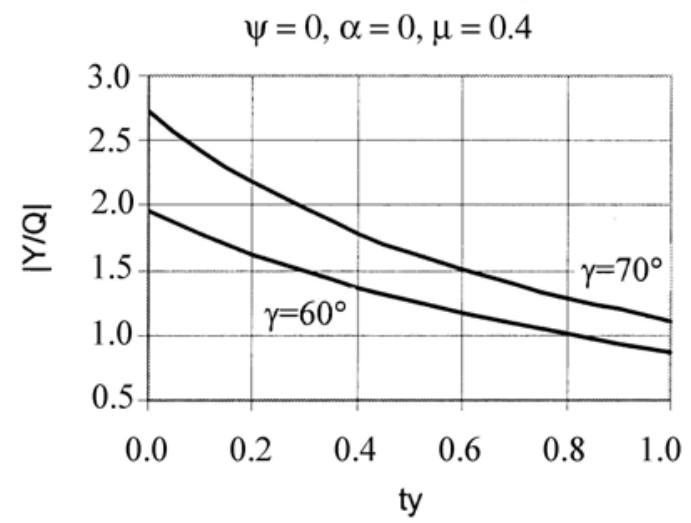

Rys.1.7. Wpływ składowej $t_{x}$ na wartość $|Y / Q|_{k r}$ dla różnych maksymalnych kątów styku obrzeża koła z szyną

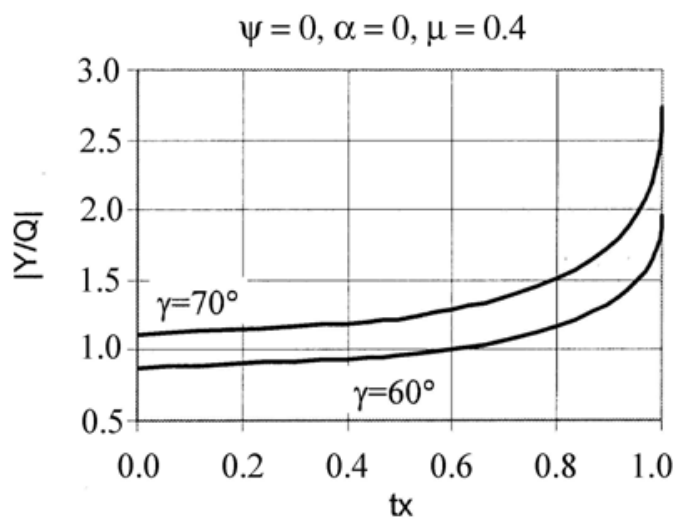

Rys.1.8. Wpływ składowej $t_{y}$ na wartość $|Y / Q|_{k r}$ dla różnych maksymalnych kątów styku obrzeża koła z szyną

$Y / Q=\frac{-t_{x} \mu \sin \psi \cos \alpha / \cos \gamma-t_{y} \mu(\cos \psi-\sin \psi \sin \alpha \operatorname{tg} \gamma)+\cos \psi \operatorname{tg} \gamma+\sin \psi \sin \alpha}{t_{x} \mu \sin \alpha / \cos \gamma+t_{y} \mu \cos \alpha \operatorname{tg} \gamma+\cos \alpha}$

Po założeniu, że $t_{x}=0, t_{y}=1, \psi=0$ oraz $\alpha=0$, z zapisu (1.4) wynika wprost równanie Nadala. Wykorzystując (1.2) oraz (1.3), ustalić można wpływ bezwymiarowych składowych $t_{x}$ oraz $t_{y}$ na wartości wskaźników $Y / Q$ w krytycznej fazie wykolejenia, traktowane dalej jako bezwzględne wartości kryterialne $|Y / Q|_{k r}$. Z punktu widzenia bezpieczeństwa ruchu pojazdu szy-
W artykule skoncentrowano się przede wszystkim na znalezieniu odpowiedzi na pytanie „czy działający krótkotrwale na zestawy kół moment napędowy lub hamujący może zmniejszyć ryzyko wykolejenia się lokomotywy na torze zakrzywionym o małym promieniu krzywizny". W tym przypadku prosta analiza, podobna do przedstawionej powyżej nie jest moż- 
liwa. Dlatego zdecydowano się wykonać serię zaplanowanych badań symulacyjnych wykorzystując możliwości obliczeniowe specjalistycznego programu Adams Rail, przeznaczonego do badania dynamiki pojazdów szynowych. W podjętych działaniach ocenę poziomu zagrożenia bezpieczeństwa sprowadzono do analizy wielkości wskaźników wykolejenia oraz sił stycznych na kołach zestawu prowadzącego, z uwzględnieniem kąta nabiegania, kąta niedostatku przechyłki toru oraz pionowych nacisków kół na szyny wynikających z położenia zestawu kół w torze zakrzywionym.

\section{Wstępne badania symulacyjne $z$ udziałem modelu lokomotywy czteroosiowej}

Wstępne badania symulacyjne $\mathrm{z}$ udziałem modelu lokomotywy czteroosiowej wyposażonej w symetryczny, indywidualny układ napędowy, wykonano na torze zakrzywionym przy założeniu, że baza lokomotywy oraz baza wózka równe są odpowiednio 11,4 m oraz 3,2 m, natomiast pionowe, statyczne naciski wywierane przez zestawy kół na tor prosty wynoszą 200 kN. Szczegółowe dane na temat modelu zbudowanego w programie Adams Rail znaleźć można w pracy [12]. Użyte do obliczeń dane mają wartości parametrów stosowanych $\mathrm{w}$ konstrukcji zawieszeń lokomotyw czteroosiowych eksploatowanych na PKP.

Model symulacyjny lokomotywy poruszał się z dopuszczalną prędkością $15 \mathrm{~m} / \mathrm{s}$ po torze zakrzywionym bez nierówności geometrycznych [2], składającym się $\mathrm{z}$ trzech sekcji opisanych na rys.2.1, tzn. odcinka toru prostego o długości $50 \mathrm{~m}$, krzywej przejściowej o długości $50 \mathrm{~m}$ oraz pełnego łuku skręcającego $\mathrm{w}$ prawą stronę, o promieniu $\mathrm{R}=150 \mathrm{~m}$ i długości 100 $\mathrm{m}$.

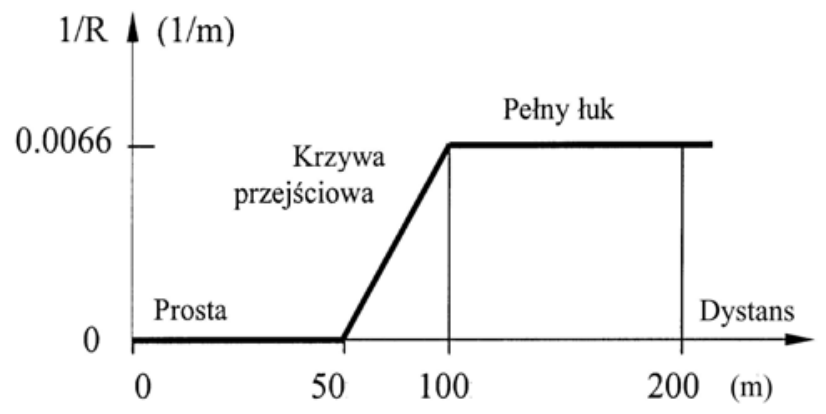

Rys.2.1. Sekcje toru zakrzywionego o promieniu łuku $\mathrm{R}=150 \mathrm{~m}-[4]$

Celem wstępnych obliczeń było ustalenie wartości kątów nabiegania oraz pionowych nacisków kół na szyny w zestawach prowadzących $\mathrm{w}$ chwili, gdy lokomotywa znajdowała się na pełnym łuku. Założono, że nominalny promień koła $r_{k} \mathrm{~W}$ zestawach wynosi $0.5 \mathrm{~m}$, natomiast współczynnik tarcia pomiędzy kołem i szyną równy jest 0.4 . Rozpatrywano unormowane profile S1002 oraz UIC60 dla kół i szyn oraz jednopunktowy, nieliniowy model kontaktu koła z szyną [3]. Wykorzystując doświadczenia własne oraz innych badaczy zdecydowano się analizować zachowanie tylko prowadzącego zestawu kół, gdyż jest on najbardziej narażony na wykolejenie - $[4,6]$. Ustalono, że podczas jazdy z dopuszczalną prędkością $15 \mathrm{~m} / \mathrm{s}$ po torze o zerowej wartości kąta niedostatku przechyłki, prowadzący zestaw kół modelu lokomotywy ustawia się pod kątem nabiegania +12 mrad, a kąt styku obrzeża koła z szyną zewnętrzną równy jest $0,78 \mathrm{rad}\left(44,7^{\circ}\right)$ - rys.2.2. Stwierdzono również, że zewnętrzne koło zestawu prowadzącego wywiera na pełnym łuku pionowy nacisk na szynę równy $130 \mathrm{kN}$, natomiast wewnętrzne nacisk $70 \mathrm{kN}$. Wykorzystując symulacyjny model lokomotywy czteroosiowej kolejne badania zrealizowano w sytuacji, w której na koła nie działał moment napędowy ani hamujący. Przyjęto przy tym następujące założenia:

1. Lokomotywa porusza się po torze zakrzywionym o promieniu krzywizny równym $150 \mathrm{~m}, \mathrm{z}$ ustaloną prędkością $v=15 \mathrm{~m} / \mathrm{s}$. Jest to prędkość dopuszczalna wyznaczona $\mathrm{z}$ godnie $\mathrm{z}[1]$.

2. Parametry toru są tak dobrane, aby w ruchu ustalonym z prędkością dopuszczalną uzyskać odpowiednią wartość kąta niedostatku przechyłki na pełnym łuku toru, w zakresie od $-3^{\circ}$ do $+3^{\circ}$.

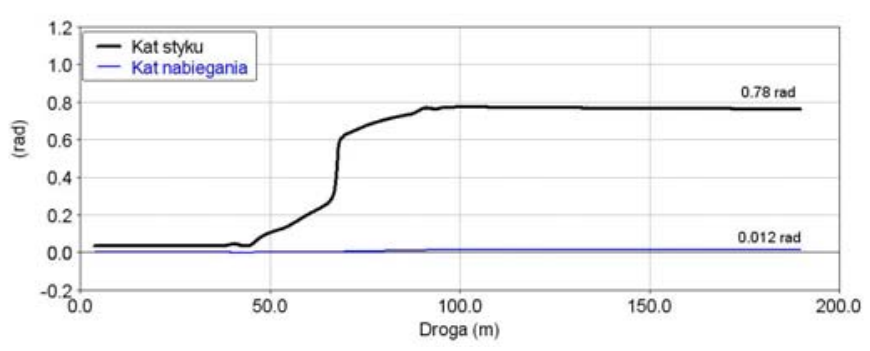

Rys.2.2. Kąt styku i kąt nabiegania zewnętrznego koła w zestawie prowadzącym lokomotywy poruszającej się z prędkością $15 \mathrm{~m} / \mathrm{s}$ po torze zakrzywionym o promieniu krzywizny $150 \mathrm{~m}$, w początkowej fazie wykolejenia

Bezwzględne wartości wskaźników wykolejenia $|Y / Q|$ na pełnym łuku w funkcji kąta niedostatku przechyłki, w odniesieniu do kół zestawu prowadzącego w wózku nr 1 lokomotywy przedstawiono rys.2.3. Na kole zewnętrznym zestawu prowadzącego daje się zauważyć umiarkowany wzrost wartości wskaźników wykolejenia, jeśli kąt niedostatku przechyłki zmienia się od ujemnych w stronę dodatnich wartości $(|Y / Q|=0,34$ dla $\Phi=-3^{\circ}$ oraz $|Y / Q|=0,39$ dla $\left.\Phi=+3^{\circ}\right)$. Największa z tych wartości jest znacznie mniejsza od dopuszczanej przez przepisy [11]. Nie występuje więc niebezpieczeństwo wykolejenia. Jednocześnie, w tym samym 
przedziale zmienności kąta niedostatku przechyłki, bezwzględne wartości wskaźników wykolejenia na kole wewnętrznym zestawu rowadzącego maleją rys.2.3.

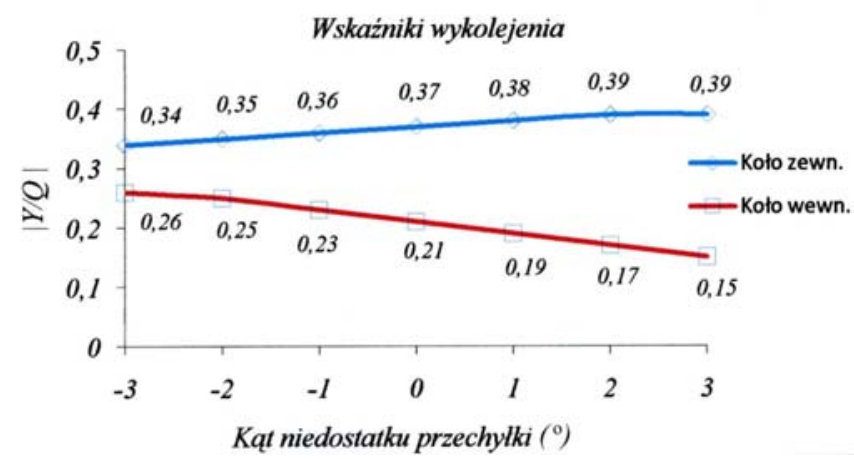

Rys.2.3. Wskaźniki wykolejenia $|Y / Q|$ na kołach zestawu prowadzącego lokomotywy poruszającej się z prędkością $15 \mathrm{~m} / \mathrm{s}, \mathrm{w}$ funkcji kąta niedostatku przechyłki toru zakrzywionego o promieniu $\mathrm{R}=150 \mathrm{~m}$, w początkowej fazie wykolejenia

\section{Analiza wplywu czasu narastania i utrzymy- wania się na docelowym poziomie wartości momentu napędowego na zwiększenie ryzyka wykolejenia się prowadzącego zestawu kół}

Poszukując odpowiedzi na zasadnicze pytanie dotyczące zagrożenia związanego $\mathrm{z}$ wykolejeniem wykonano kolejne badania symulacyjne $\mathrm{z}$ udziałem symulacyjnego modelu lokomotywy w celu ustalenia wpływu czasu narastania i utrzymywania się docelowej wartości momentu napędowego lub hamującego na ryzyko wykolejenia powstającego $\mathrm{w}$ wyniku wspinania się obrzeża koła na główkę szyny. Na podstawie wcześniej zgromadzonych wyników obliczeń - rys.2.3 stwierdzono, że przy prędkości $15 \mathrm{~m} / \mathrm{s}$ wskaźnik wykolejenia na najbardziej zagrożonym kole równy jest 0,39 . Dla porównania jest to wartość dużo mniejsza od wartości $Y / Q=0,708$ obliczonej z równania Nadala dla kąta styku pomiędzy kołem i szyną równego $60^{\circ}$ oraz przy założeniu, że współczynnik tarcia wynosi 0,4 . Na tym etapie badań zajęto się analizą skutków chwilowego działania momentu napędowego, którego efektem będzie zwiększenie (ponad dopuszczalną) prędkości lokomotywy wzdłuż toru. Trzy wartości momentu napędowego równe odpowiednio $10 \mathrm{kNm}$, $20 \mathrm{kNm}$ oraz $30 \mathrm{kNm}$, przykładano do osi zestawów kół lokomotywy w chwili, gdy ta poruszając się ruchem ustalonym z prędkością $15 \mathrm{~m} / \mathrm{s}$ wjeżdżała na pełny łuku toru o promieniu krzywizny $150 \mathrm{~m}$. Ostatnia $\mathrm{z}$ wartości momentu napędowego traktowana była jako wartość graniczna ze względu na możliwość utraty przyczepności kół. Oszacowano ją przy założeniach, że maksymalny nacisk statyczny zestawu kół na szyny równy jest $200 \mathrm{kN}$, średnica koła wynosi $1 \mathrm{~m}$ oraz współczynnik tarcia pomiędzy kołem i szyną mieści się $\mathrm{w}$ przedziale wartości od 0,3 do 0,4 . Charakterystyki branych pod uwagę momentów napędo- wych przedstawiono na rys.3.1. W każdym z trzech wyróżnionych przypadków moment napędowy wprowadzany był od 7 sekundy i narastał od zera do wartości docelowej w czasie 0,1 sekundy, 5 sekund oraz 10 sekund. Po osiagnięciu wartości maksymalnej moment napędowy utrzymywany był przez 2 sekundy na stałym poziomie, następnie redukowano go do zera. Ustalono, że czas narastania $t_{n}$ momentu napędowego powinien być krótki (w granicach $0,1 \mathrm{~s}$ ), natomiast czas $t$ utrzymywania się maksymalnej wartości tego momentu nie może przekraczać 2 sekund.

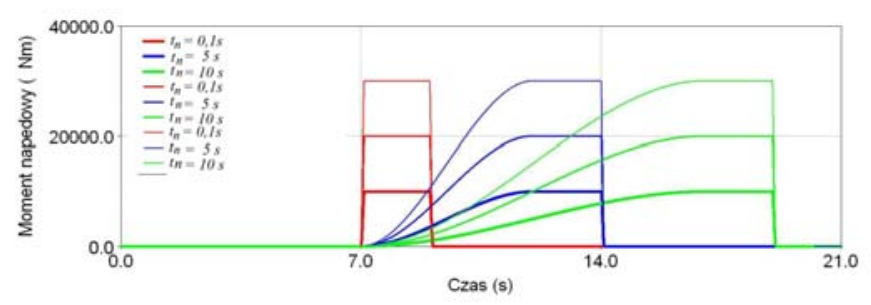

Rys.3.1. Charakterystyki branych pod uwagę momentów napędowych na osiach zestawów kół lokomotywy

Traktując kąt styku obrzeża koła wspinającego się na szynę zewnętrzną jako parametr pomocniczy w ocenie zagrożenia wykolejeniem stwierdzono, że $\mathrm{w}$ ruchu modelu lokomotywy po torze zakrzywionym o małym promieniu krzywizny najkorzystniejszy jest przypadek, w którym chwilowy moment napędowy osiaga docelową wartość $30 \mathrm{kNm}$. Wówczas znacząco zmniejsza się wartość kąta styku koła szyną (od ok. $40^{\circ}$, gdy moment nie działa, do ok. $15^{\circ}$, gdy moment napędowy występuje) - czerwona linia na rys.3.2. Zauważono jednocześnie, że zbyt mała wartość momentu napędowego (w badanych przypadkach 10 $\mathrm{kNm}$ ) podnosi nieznacznie poziom zagrożenia $\mathrm{w}$ porównaniu z sytuacja, gdy moment napędowy nie występuje - niebieska linia na rys.3.2. Wielkość kąta styku zwiększa się wówczas z $40^{\circ}$ do ok. $44^{\circ}$. Do potwierdzenia tezy o zasadności stosowania krótkiego czasu narastania momentu napędowego wykorzystano rys.3.3. Najbardziej obiecujący jest przypadek, w którym czas $t_{n}=0,1 \mathrm{~s}$, gdyż towarzyszy mu najszybsze $\mathrm{i}$ największe chwilowe zmniejszenie się wartości kąta styku podczas utrzymywania się docelowej wartości momentu napędowego. Jednocześnie czas ten jest wystarczająco krótki, by nie pozwolić modelowi rozpędzić się do prędkości, przy której główną przyczyną wykolejenia będzie siła odśrodkowa działająca na pojazd.

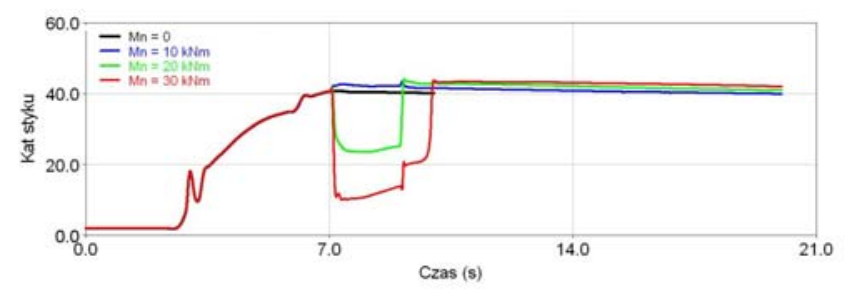


Rys.3.2. Zmiana katów styku w funkcji czasu na torze zakrzywionym o promieniu $150 \mathrm{~m}$, na zewnętrznym kole zestawu prowadzącego lokomotywy poruszającej się z prędkością $15 \mathrm{~m} / \mathrm{s}$, w początkowej fazie wykolejenia w zależności od wielkości momentu napędowego

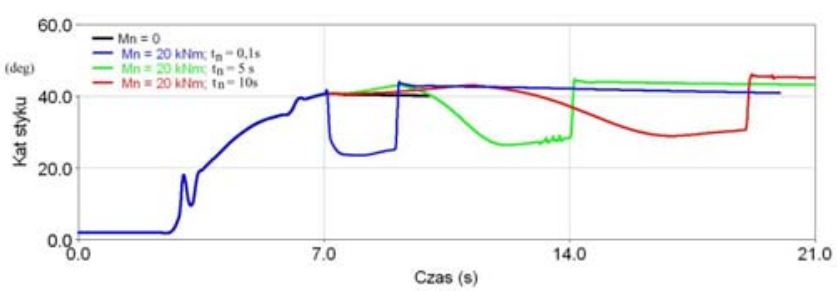

Rys.3.3. Zmiana kątów styku w funkcji czasu na torze zakrzywionym o promieniu $150 \mathrm{~m}$, na zewnętrznym kole zestawu prowadzącego lokomotywy poruszającej się z prędkością $15 \mathrm{~m} / \mathrm{s}$, w początkowej fazie wykolejenia w zależności od czasu trwania docelowej wielkości momentu napędowego

Wnioski wskazujące na celowość stosowania chwilowo działającego momentu napędowego o odpowiednio dużej wielkości wypływają również z analizy wartości wskaźników wykolejenia na zewnętrznym kole zestawu prowadzącego $\mathrm{w}$ modelu lokomotywy, przy różnych wartościach kąta niedostatku przechyłki toru rys.3.4. Wartości wskaźników $|Y / Q|$ najmniejsze są wtedy, gdy moment napędowy równy jest $30 \mathrm{kNm}$, natomiast mały moment napędowy ( $\mathrm{w}$ zakresie od 0 do $10 \mathrm{kNm}$ ) zwiększa bezwzględną wartość wskaźnika wykolejenia, co jest niekorzystne z punktu widzenia bezpieczeństwa ruchu. Tym samym potwierdzony został wcześniejszy wniosek sugerujący, że za optymalną uznać należy wartość momentu napędowego Mn równą $30 \mathrm{kNm}$, gdyż towarzyszy jej obniżenie wartości wskaźnika wykolejenia $|Y / Q|$ od 0,39 (dla $\left.M_{n}=0\right)$ do $0,25\left(\right.$ dla $\left.M_{n}=30 \mathrm{kNm}\right)$ przy niedostatku przechyłki $+3^{\circ}$ oraz zmniejszenie tej samej wartości $|Y / Q|$ od 0,34 (dla $\left.M_{n}=0\right)$ do 0,17 (dla $M_{n}=30 \mathrm{kNm}$ ) przy niedostatku przechyłki $-3^{\circ}$. W pierwszym przypadku jest to spadek procentowy o ok. $36 \%$, w drugim o ok. $50 \%$.

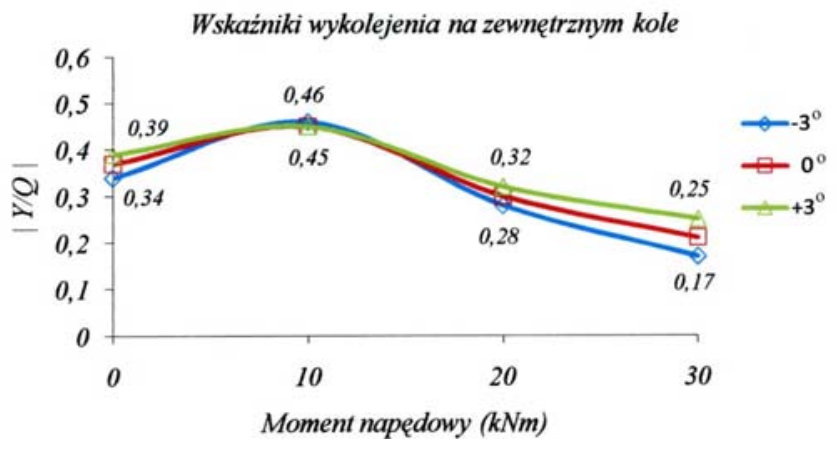

Rys.3.4. Zmiana bezwzględnych wartości wskaźników wykolejenia na zewnętrznym kole zestawu prowadzącego lokomotywy poruszającej się z prędkością $15 \mathrm{~m} / \mathrm{s}$, w funkcji momentu napędowego w początkowej fazie wykolejenia na torze zakrzywionym o promieniu $150 \mathrm{~m}$

\section{Kontrolowane wykolejenie pomiarowego ze- stawu kół z uwzględnieniem momentu hamują- cego lub napędowego}

Wykonane wcześniej badania symulacyjne nie kończyły się wykolejeniem modelu lokomotywy, co umożliwiłoby zarejestrowanie wartości parametrów w krytycznej fazie tego procesu. Dlatego za stosowne uznano rozszerzenie zakresu badań. W tym celu wykorzystano opisany w [8] wirtualny pojazd badawczy, umieszczając pod jego nadwoziem pomiarowy zestaw kół, na który mogą działać jednocześnie moment hamujący lub napędowy oraz zewnętrzna siła poprzeczna umożliwiająca kontrolowane wykolejenie. Zbudowany w programie Adams Rail model pojazdu badawczego składał się z nadwozia 1 , zestawów kół 6 , ramy prowadzącej 2 , sztywnej ramki 3 , połączonej $z$ pomiarowym zestawem kół 4 oraz elementów zawieszenia 5 zestawu pomiarowego - rys.4.1.

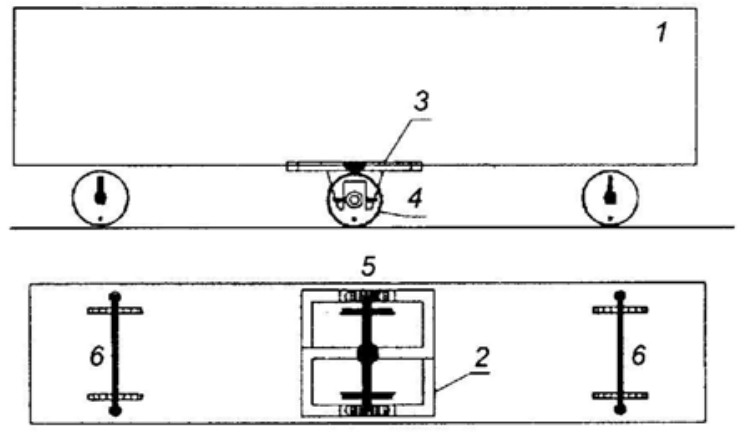

Rys.4.1. Elementy symulacyjnego modelu pojazdu badawczego $\mathrm{z}$ pomiarowym zestawem kół w programie Adams Rail - [4]

Ustawienie pomiarowego zestawu kół w torze umożliwiały odpowiednie pary kinematyczne zastosowane w strukturze pojazdu badawczego. Do obrócenia ramy prowadzącej względem nadwozia, wykorzystano kinematyczną parę obrotową piątej klasy, która umożliwiała pomiarowemu zestawowi kół przyjęcie odpowiedniej wartości kąta nabiegania w płaszczyźnie poziomej. Para kinematyczna, reprezentująca punkt przemieszczający się po płaszczyźnie, pozwalała na przemieszczanie się pomiarowego zestawu kół w płaszczyźnie pionowej. Pionowe obciążenie przenoszone było z nadwozia na elementy zawieszenia, a następnie na koła zestawu pomiarowego. Kontrolowane wykolejenie pomiarowego zestawu kół następowało w wyniku działania zewnętrznej siły poprzecznej przyłożonej na poziomie główek szyn, wywieranej $\mathrm{w}$ zaplanowany sposób pomiędzy nadwoziem pojazdu badawczego i zestawem pomiarowym w czasie, w którym na zestaw kół działał moment napędowy lub hamujący. W ten sposób wyznaczono wartości wskaźników $|Y / Q|$ w krytycznej fazie kontrolowanego wykolejenia pomiarowego zestawu kól. Wartości te traktowano następnie jako kryterialne wskaźniki wykolejenia, weryfikujące wartości wynikające $\mathrm{z}$ kryterium 
Nadala. Badania symulacyjne kontrolowanego wykolejenia pomiarowego zestawu kół spełniały następujące założenia:

- Wymiary geometryczne oraz profil kół zestawu pomiarowego odpowiadały wymiarom i profilom stosowanym w zestawach kół w badanym wcześniej modelu lokomotywy czteroosiowej.

- Pomiarowy zestaw kół ustawiany był pod nadwoziem pojazdu badawczego pod kątem nabiegania +12 mrad. Taką wartość (zarejestrowaną wcześniej podczas przejazdu modelu lokomotywy ze stała prędkością $15 \mathrm{~m} / \mathrm{s}$ ) utrzymywano przez cały czas kontrolowanego wykolejenia, do którego doprowadzano na pełnym łuku o promieniu $150 \mathrm{~m}$.

- Zewnętrzne koło zestawu pomiarowego obciążone zostało siłą pionową równą $130 \mathrm{kN}$, natomiast koło wewnętrzne siłą $70 \mathrm{kN}$, co również wynika $\mathrm{z}$ wcześniej wykonanych symulacji z udziałem modelu lokomotywy.

- Poprzeczna siła zewnętrzna, powodująca wykolejenie pomiarowego zestawu kół, przykładana była w chwili pojawienia się momentu hamującego lub napędowego i narastała $\mathrm{z}$ taką prędkością, aby proces wykolejenia mógł rozpocząć się i zakończyć się na pełnym łuku toru zakrzywionego w czasie, w którym działał również wspomniany moment.

- Momenty hamujące lub napędowe (o wartościach docelowych $10 \mathrm{kNm}, 20 \mathrm{kNm}, 30 \mathrm{kNm}$ ) przykładane były gwałtownie ( $\mathrm{w}$ czasie narastania $t_{n}=0,1 \mathrm{~s}$ ), utrzymywano je na stałym poziomie przez $2 \mathrm{~s}$, następnie wartości tych momentów redukowano do zera. Na rys.4.2 przedstawiono zmiany wartości kątów sty$\mathrm{ku}$ obrzeża koła wspinającego się na szynę $\mathrm{w}$ funkcji czasu przy braku momentu napędowego i dla dwóch wybranych wartości momentu napędowego $(20 \mathrm{kNm}$ oraz $30 \mathrm{kNm}$ ), przy zerowym kącie niedostatku przechyłki toru. Na tle zmian wartości kątów styku przykładowo wrysowano przebieg momentu napędowego o docelowej wartości $20 \mathrm{kNm}$.

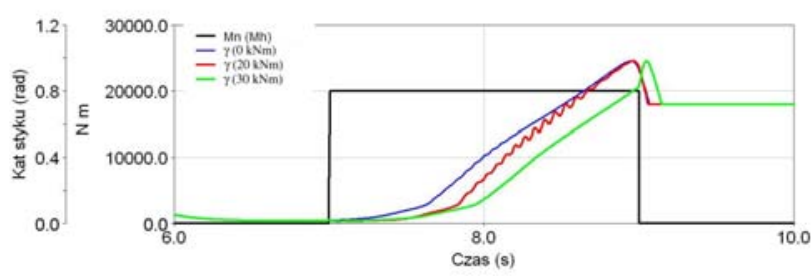

Rys.4.2. Zmiana w czasie wartości kątów styku obrzeża koła wspinającego się na szynę dla trzech wybranych wartości momentu napędowego, przy zerowym kącie niedostatku przechyłki toru zakrzywionego o promieniu $150 \mathrm{~m}$, w krytycznej fazie wykolejenia

Zmiany wartości kąta styku (zielona linia) oraz odpowiadające im wartości wskaźnika wykolejenia $|Y / Q|$ (czarna linia) w przypadku, gdy moment napędowy równy był $30 \mathrm{kNm}$, pokazano na rys.4.3. Proces kontrolowanego wykolejenia rozpoczyna się tutaj od 7 sekundy, tzn. bezpośrednio po przyłożeniu poprzecznej siły zewnętrznej. Od tej chwili kąt styku obrzeża koła z szyną zwiększa się, osiagając w punkcie krytycznym maksymalną wartość $1.02 \mathrm{rad}\left(58.7^{\circ}\right)$. Dalsze wspinanie się obrzeża koła nabiegającego na główkę szyny prowadzi do zmniejszania się kąta styku, który po czasie ok. 9,2 s osiaga wartość minimalną równą $0.75 \mathrm{rad}\left(42.8^{\circ}\right)$. Następuje wówczas końcowa faza procesu wykolejenia. Obrzeże koła wjeżdża na główkę szyny i pomiarowy zestaw kół opuszcza tor. Na rys.4.3 maksymalnej wartości kąta styku obrzeża $\mathrm{z}$ główką szyny odpowiada szczytowa, bezwzględna wartość wskaźnika wykolejenia, która w dalszych analizach traktowana jest jako wartość kryterialna $|Y / Q|_{k r}$. W tym konkretnym przypadku jest to wartość 0,94 .

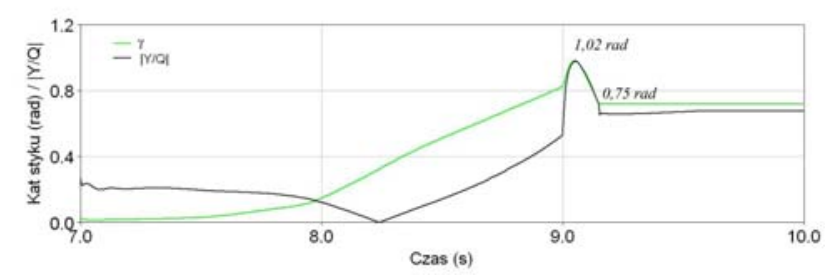

Rys.4.3. Zmiana w czasie wartości kąta styku obrzeża koła wspinającego się na szynę i odpowiadające mu wartości wskaźnika wykolejenia przy zerowym kącie niedostatku przechyłki toru zakrzywionego o promieniu $150 \mathrm{~m}$ oraz momencie napędowym $30 \mathrm{kNm}$, w krytycznej fazie wykolejenia

Następne badania symulacyjne, dotyczące kontrolowanego wykolejenia pomiarowego zestawu kó1, wykonano przy trzech wartościach kąta niedostatku przechyłki: $-3^{\circ}, 0^{\circ}$ oraz $+3^{\circ}$. Tym razem przedmiotem zainteresowania były kryterialne wartości wskaźników wykolejenia na pojedynczym kole $\mathrm{w}$ funkcji momentu napędowego i hamującego, zmieniającego się w zakresie od 0 do $30 \mathrm{kNm}$. Wyniki przedstawiono kolejno na rys.4.4 oraz rys.4.5. Stwierdzono, że zarówno moment napędowy, jak i hamujący przyczyniają się do zwiększenia kryterialnej wartości wskaźnika wykolejenia na pojedynczym kole. Jest to zależność wprost proporcjonalna, tzn. większej wartości momentu odpowiada większa wartość $|Y / Q|_{k r}$, oznaczająca mniejszą skłonność do wykolejenia, a tym samym większy zapas bezpieczeństwa. Uzyskane wyniki wskazują na to, że większy zapas bezpieczeństwa zagwarantować można pojazdowi, jeśli ten porusza się po torze zakrzywionym o ujemnym kącie niedostatku przechyłki.

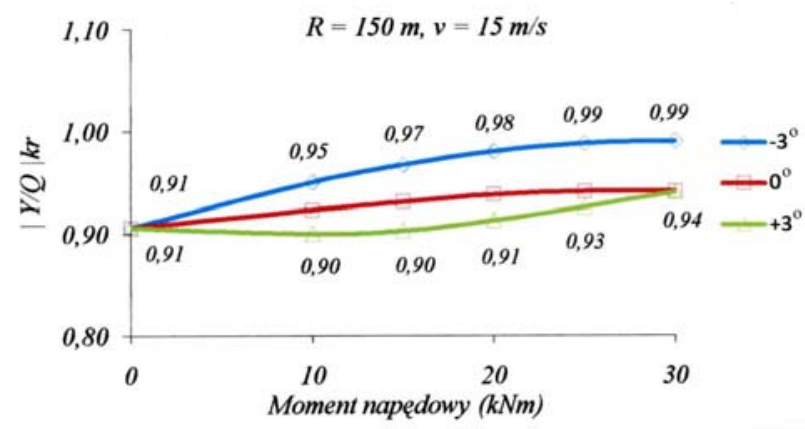


Rys.4.4. Zmiana bezwzględnych, kryterialnych wartości wskaźników wykolejenia na zewnętrznym kole zestawu prowadzącego lokomotywy poruszającej się z prędkością $15 \mathrm{~m} / \mathrm{s}$, w funkcji momentu napędowego w krytycznej fazie wykolejenia na torze zakrzywionym o promieniu $150 \mathrm{~m}$

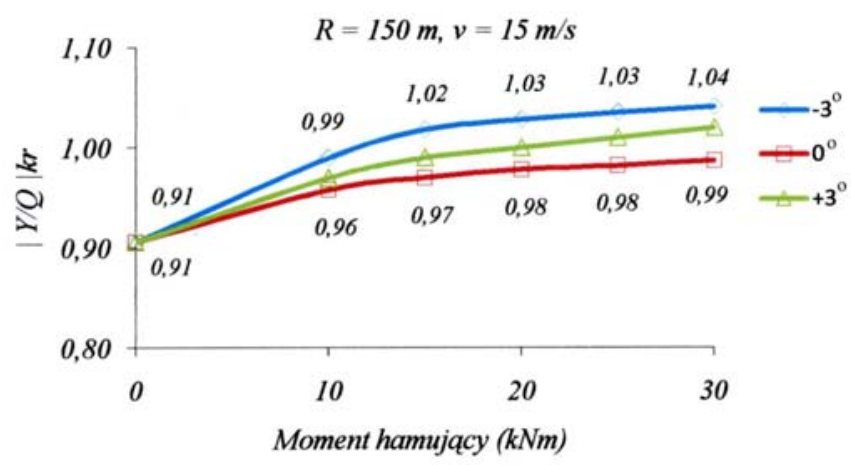

Rys.4.5. Zmiana bezwzględnych, kryterialnych wartości wskaźników wykolejenia na zewnętrznym kole zestawu prowadzącego lokomotywy poruszającej się z prędkością $15 \mathrm{~m} / \mathrm{s}$, w funkcji momentu hamującego w krytycznej fazie wykolejenia na torze zakrzywionym o promieniu $150 \mathrm{~m}$

\section{Udzial sil stycznych $w$ procesie wykolejenia koła wspinającego się na szynę}

Ocenie poddano wzdłużne i poprzeczne siły styczne w obszarze styku pojedynczego (zewnętrznego) koła z szyną w funkcji momentu napędowego, dla trzech wartości kąta niedostatku przechyłki. Przedstawione na rys.5.1 wyniki współgrają z zaprezentowanymi wcześniej na rys.3.4 wynikami badań, uzyskanymi w początkowej fazie wykolejenia prowadzącego zestawu kół w wózku nr 1 lokomotywy. Do analizy wybrano przypadek zerowego kąta niedostatku przechyłki.

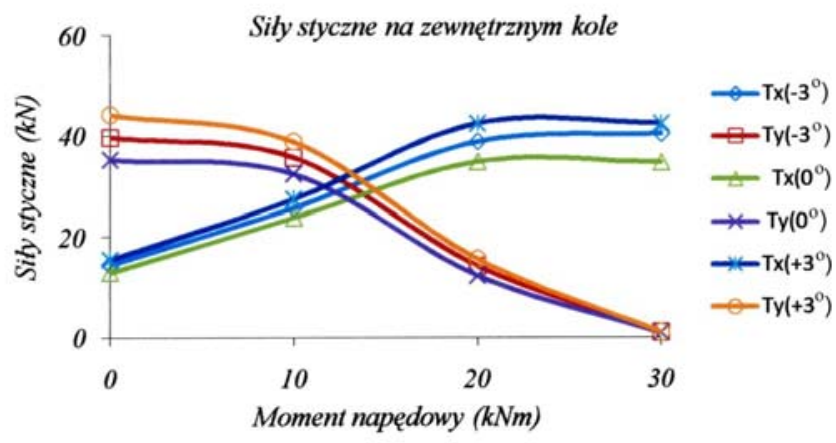

Rys.5.1. Wartości sił stycznych na zewnętrznym kole zestawu prowadzącego lokomotywy poruszającej się z prędkością $15 \mathrm{~m} / \mathrm{s}$, w funkcji momentu napędowego w początkowej fazie wykolejenia na torze zakrzywionym o promieniu $150 \mathrm{~m}$

W chwili, gdy na oś prowadzącego zestawu kół nie działa moment napędowy, obserwujemy duże wartości poprzecznych sił stycznych $T_{y}$ (na poziomie $35 \mathrm{kN}$ ) oraz prawie dwukrotnie mniejsze wartości wzdłużnych sił stycznych $T_{x}$. Wielkości tych sił zrównują się po zwiększeniu momentu napędowego do ok. $12 \mathrm{kNm}$.
Dalszemu wzrostowi momentu napędowego towarzyszy odwrócenie relacji pomiędzy wielkościami sił stycznych. Gdy moment osiąga wartość graniczną 30 $\mathrm{kNm}$, siły poprzeczne zmniejszają się do wartości kilku $\mathrm{kN}$, natomiast siły wzdłużne rosną i stabilizują się na poziomie ok. $35 \mathrm{kN}$. Taka relacja pomiędzy siłami stycznymi uzasadnia przytoczony wcześniej wniosek, że granicznej wartości momentu napędowego odpowiada największy poziom bezpieczeństwa $\mathrm{w}$ badanym przedziale zmienności momentu napędowego, gdyż wówczas wzdłużne siły styczne są największe.

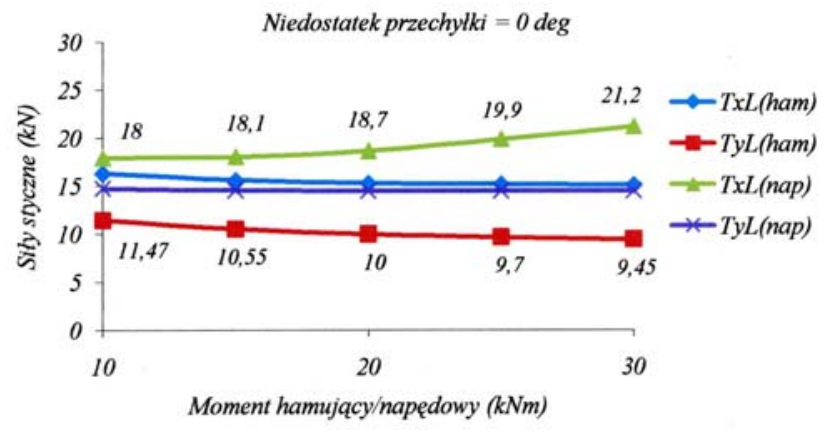

Rys.5.2. Wartości sił stycznych na zewnętrznym kole zestawu prowadzącego lokomotywy poruszającej się z prędkością $15 \mathrm{~m} / \mathrm{s}$, w funkcji momentu napędowego w krytycznej fazie wykolejenia na torze zakrzywionym o promieniu $150 \mathrm{~m}$

Wyniki przedstawione na rys.5.2 zapisane zostały w krytycznej fazie kontrolowanego wykolejenia w funkcji działającego na oś zestawu kół momentu hamującego lub napędowego, przy zerowej wartości kąta niedostatku przechyłki toru. Obserwacja przebiegu sił stycznych prowadzi do następujących wniosków:

1) Zwiększanie momentu hamującego lub napędowego w krytycznej fazie wykolejenia w nieznacznym stopniu wpływa na zmianę wartości wzdłużnych i poprzecznych sił stycznych.

2) W przypadku działania momentu hamującego wzdłużna siła styczna $T_{x}$ zmniejsza się od ok. $17 \mathrm{kN}$ (przy momencie $10 \mathrm{kNm}$ ) do ok. $16 \mathrm{kN}$, gdy ten moment osiaga wartość $30 \mathrm{kNm}$; poprzeczna siła styczna $T_{y}$ ma podobny przebieg, a jej wartość zmniejsza się od $11,47 \mathrm{kN}$ do $9,45 \mathrm{kN}$ w badanym zakresie przyrostu momentu hamującego.

3) Gdy działa moment napędowy, wzdłużna siła styczna $T_{x}$ zwiększa się od ok. $18 \mathrm{kN}$ (przy momencie $10 \mathrm{kNm}$ ) do ok. $21,2 \mathrm{kN}$, gdy ten moment osiaga wartość $30 \mathrm{kNm}$; poprzeczna siła styczna $T_{y}$ praktycznie utrzymuje się na jednakowym poziomie $15 \mathrm{kN}$.

4) $Z$ punktu widzenia bezpieczeństwa ruchu relacja pomiędzy siłami stycznymi jest korzystna, tzn. wzdłużne siły styczne są większe od sił poprzecznych zarówno

w przypadku momentu hamującego, jak i momentu napędowego;.

5) W przypadku działania momentu hamującego udział wzdłużnych sił stycznych jest w przybliżeniu o 
ok. 30\% większy niż poprzecznych sił stycznych (w porównaniu

z przypadkiem działania momentu napędowego) W całym zakresie zmian momentu. Potwierdzają to większe wartości kryterialne wskaźników wykolejenia, gdy uwzględniany jest moment hamujący (rys.4.5), w porównaniu z podobnymi wskaźnikami, gdy występuje moment napędowy (rys.4.4).

\section{Podsumowanie}

Przedstawiona $\mathrm{w}$ artykule dyskusja ukierunkowana została na bezpieczeństwo lokomotywy czteroosiowej poruszającej się z dopuszczalną prędkością po torze zakrzywionym o małym promieniu krzywizny. Analizowano proces wykolejenia będący wynikiem wspinania się obrzeża koła na główkę szyny. Dyskusja w znacznej części dotyczyła udziału i roli sił stycznych w obszarze styku obrzeża koła z szyna, zarówno w odniesieniu do początkowej, jak i krytycznej fazy wykolejenia. Skoncentrowano się przede wszystkim na znalezieniu odpowiedzi na pytanie „czy krótkotrwale działający na zestawy kół moment napędowy lub hamujący może zmniejszyć ryzyko wykolejenia się lokomotywy na torze zakrzywionym o małym promieniu krzywizny". Ze względu na duży stopień skomplikowania problemu zdecydowano się wykorzystać możliwości obliczeniowe specjalistycznego programu Adams Rail, przeznaczonego do badania dynamiki pojazdów szynowych. We wszystkich podjętych działaniach ocenę poziomu zagrożenia sprowadzono do analizy wskaźników wykolejenia na kołach zestawu prowadzącego, z uwzględnieniem kąta nabiegania, kąta niedostatku przechyłki toru oraz pionowych nacisków kół na szyny wynikających z położenia zestawu kół w torze zakrzywionym.

Ustalono, że podczas jazdy z dopuszczalną prędkością $15 \mathrm{~m} / \mathrm{s}$ po torze zakrzywionym o promieniu krzywizny równym $150 \mathrm{~m}$ oraz przy zerowej wartości kąta niedostatku przechyłki, dochodzi do początkowej fazy wykolejenia, w której prowadzący zestaw w kół modelu lokomotywy ustawia się na pełnym łuku pod dodatnim kątem nabiegania +12 mrad, a kąt styku obrzeża koła $z$ szyną zewnętrzną równy jest $0,78 \mathrm{rad}(44,7 \mathrm{deg})$. Stwarza to warunki kołnierzowego prowadzenia zestawu kół. Największa z wartości $|Y / Q|$ wskaźników wykolejenia jest jednak znacznie mniejsza od granicznej wartości, dopuszczanej przez przepisy kolejowe. Tym samym nie występuje niebezpieczeństwo opuszczenia toru przez prowadzący zestaw kół w wyniku wspinania się obrzeża koła na główkę szyny.

Badając wpływ czasu narastania i utrzymywania się docelowej wartości momentu napędowego i hamującego na ryzyko wykolejenia powstającego w wyniku wspinania się obrzeża koła na główkę szyny ustalono, że najkorzystniejszy jest przypadek, w którym czas narastania jest krótki (wynosi ok. $0,1 \mathrm{~s}$ ), natomiast czas utrzymywania się maksymalnej wartości momentów nie przekracza 2 sekund. Stwierdzono również, że w ruchu modelu lokomotywy po torze zakrzywionym o małym promieniu krzywizny jako optymalną uznać należy wartość momentu napędowego równą $30 \mathrm{kNm}$, gdyż towarzyszy jej obniżenie wartości wskaźnika wykolejenia $|Y / Q|$ od 0,39 (dla $\left.M_{n}=0\right)$ do 0,25 (dla $M_{n}=30 \mathrm{kNm}$ ) przy niedostatku przechyłki $+3^{\circ}$ oraz zmniejszenie tej samej wartości $|Y / Q|$ od 0,34 (dla $\left.M_{n}=0\right)$ do $0,17\left(\right.$ dla $\left.M_{n}=30 \mathrm{kNm}\right)$ przy niedostatku przechyłki $-3^{\circ}$. W pierwszym przypadku jest to spadek procentowy o ok. $36 \%$, w drugim o ok. 50\%. Obniżenie wartości wskaźników wykolejenia oznacza tutaj zwiększenie zapasu bezpieczeństwa i jest pożądane.

Rozszerzone badania symulacyjne wykolejenia modelu lokomotywy umożliwiły zarejestrowanie wartości wskaźników wykolejenia oraz sił stycznych w obszarze styku obrzeża koła z szyną w krytycznej fazie tego procesu. W tym celu wykorzystano wirtualny pojazd badawczy z umieszczonym pod jego nadwoziem pomiarowym zestawem kół, na który działały jednocześnie moment hamujący lub napędowego oraz zewnętrzna siła poprzeczna umożliwiająca kontrolowane wykolejenie. Stwierdzono pewną ogólną prawidłowość z której wynika, że w procesie wykolejenia zestawu kół maksymalnej wartości kąta styku obrzeża koła z szyną odpowiada szczytowa, bezwzględna wartość wskaźnika wykolejenia, która może być traktowana $\mathrm{w}$ dalszych analizach jako wartość kryterialna $|Y / Q|_{k r}$.

Jednoznacznie stwierdzono, że zarówno moment napędowy, jak i hamujący przyczyniają się do zwiększenia kryterialnej wartości wskaźnika wykolejenia na pojedynczym kole. Jest to zależność wprost proporcjonalna, tzn. większej wartości momentu odpowiada większa wartość $|Y / Q|_{k r}$, oznaczająca większy zapas bezpieczeństwa. Uzyskane wyniki wskazują również na to, że większe bezpieczeństwo gwarantuje pojazdowi jazda po torze zakrzywionym o ujemnym kącie niedostatku przechyłki.

Stwierdzono, że w krytycznej fazie wykolejenia moment hamujący odgrywa pozytywniejszą rolę w próbie zwiększenia bezpieczeństwa $\mathrm{w}$ ruchu po torze zakrzywionym o małym promieniu krzywizny, jakkolwiek moment napędowy również przyczynia się do podniesienia tego poziomu. Analizując wyniki w kategorii przyrostów procentowych ustalono, że w przypadku momentu napędowego kryterialna wartość wskaźnika wykolejenia zwiększa się od 0,91 (gdy $\left.M_{n}=0\right)$ do 0,94 (gdy $\left.M_{n}=30 \mathrm{kNm}\right)$, co odpowiada przyrostowi wartości o ok. 3,3\%. Taki sam przyrost $\mathrm{w}$ odniesieniu do momentu hamującego kształtuje się na poziomie $8,8 \%$. Nie są to duże przyrosty, ale godne zauważenia, ponieważ wyraźnie potwierdzają tezę, że zarówno moment napędowy, jak i moment hamujący korzystnie przyczynia się do zwiększenia poziomu bezpieczeństwa lokomotywy czteroosiowej poruszają- 
cej się po torze zakrzywionym o małym promieniu krzywizny.

Ocenie poddano również wzdłużne i poprzeczne siły styczne w obszarze styku pojedynczego koła z szyną w początkowej i krytycznej fazie wykolejenia. W początkowej fazie wykolejenia, w sytuacji gdy na oś zestawu kół nie działa moment napędowy, w obszarze kontaktu koła z szyną występują duże wartości poprzecznych sił stycznych $T_{y}$ (na poziomie $35 \mathrm{kN}$ ) oraz prawie dwukrotnie mniejsze wartości wzdłużnych sił stycznych $T_{x}$. Siły te zrównują się po zwiększeniu momentu napędowego do ok. $12 \mathrm{kNm}$. Dalszemu wzrostowi momentu napędowego towarzyszy odwrócenie relacji pomiędzy wielkościami sił stycznych. Gdy moment osiaga wartość graniczną $30 \mathrm{kNm}$, siły poprzeczne zmniejszają się do wartości kilku kN, natomiast siły wzdłużne rosną i stabilizują się na poziomie ok. 35 kN. Taka relacja pomiędzy siłami stycznymi potwierdza wcześniejszy wniosek sugerujący, że w początkowej fazie wykolejenia możliwie duża wartość (30 kNm) działającego przez 2 sekundy momentu napędowego zapewnia największy poziom bezpieczeństwa w badanym przedziale zmienności momentu napędowego.

Obserwacja przebiegu sił stycznych w krytycznej fazie kontrolowanego wykolejenia prowadzi do wniosku, że w przypadku chwilowego działania momentu hamującego wielkości wzdłużnych sił stycznych są większe prawie o 30\% od wielkości poprzecznych sił stycznych (w porównaniu z przypadkiem, w którym działa moment napędowy) w całym zakresie zmian tego momentu. Umożliwia to uzyskanie większych wartości kryterialnych wskaźników wykolejenia w sytuacji hamowania zestawu kół. Procentowe różnice pomiędzy kryterialnymi wartościami wskaźników w krytycznej fazie wykolejenia wynoszą ok. 5,5\% na korzyść momentu hamującego.

Artykuł powstał w ramach pracy statutowej

„Symulacyjne badanie wpływu momentu napędowego oraz momentu hamującego zestawy kół na zagrożenie wykolejeniem pojazdu w ruchu po torze zakrzywionym"

\section{Literatura}

[1] Bałuch, H.: Optymalizacja układów geometrycznych toru. Warszawa. WKE, 1983.

[2] Elkins, J.A.; Carter, A.: Testing and Analysis Techniques for Safety Assessment of Rail Vehicles. Vehicle System Dynamics, No. 2, 1993, pp. 185-208.

[3] Kalker, J.J.: Three-Dimensional Elastic Bodies in Rolling Cotntact. Kluwer Academic Publishers. Dordrecht/Boston/London, 1990.

[4] Matej, J.: Modelowanie oraz symulacyjne badania wagonów bimodalnych $w$ kategoriach zagrożenia wykolejeniem. Prace Naukowe Politechniki Warszawskiej, Mechanika, z. 234. Oficyna Wydawnicza Politechniki Warszawskiej, Warszawa 2010.

[5] Matej, J.: Symulacyjna metoda oceny poziomu zagrożenia wykolejeniem wagonu towarowego na torze prostym. Przeglad Mechaniczny, Nr1/2011.

[6] Piotrowski, J.: Poprzeczne oddziaływania między pojazdem $i$ torem - podstawy modelowania numerycznego. Prace Naukowe PW, Mechanika, z. 118, Warszawa, 1992.

[7] Santamaria, J.; Vadillo, E.G.; Gomez, J.: Influence of creep forces on the risk of derailment of railway vehicles. Vehicle System Dynamics, Vol. 47, No. 6, June 2009, pp. 721-752.

[8] Seńko, J.: Model symulacyjny pojazdu badawczego z pomiarowym zestawem kół. Opracowanie wewnętrzne Instytutu Pojazdów Politechniki Warszawskiej. Warszawa 2010.

[9] Sobaś, M.: Stan I doskonalenie kryteriów bezpieczeństwa przed wykolejeniem pojazdów szynowych (1). Pojazdy Szynowe, nr 4/2005. Str. 1-13.

[10]Shust, W.; Elkins, J.: Wheel forces during flange climb. Part I - track loading vehicle tests. Transportation Technology Center, Association of American Railroads, Pueblo, Colorado 1997.

[11]UIC Code 518.: Testing and approval of railway vehicles from the point of view of dynamic behaviour. Safety, track fatigue ride quality. International Union of Railways, $2^{\text {nd }}$ edition, April 2003.

[12]Zaborowski, J.: Badanie wptywu struktury układu napędowego na bezpieczeństwo ruchu pojazdu szynowego. Rozprawa doktorska. Politechnika Warszawska, Wydziat SiMR, 2006. 